\title{
ANALISIS KEMAMPUAN PEMECAHAN MASALAH PADA SISWA SMP MANIAMAS NGABANG
}

\author{
JELIANA INTAN PERMATA ${ }^{1}$, YOHANES SANDRI ${ }^{2}$ \\ ${ }^{1}$ Program Studi Pendidikan Matematika STKIP Pamane Talino, Jalan Afandi Rani, Ngabang, Landak, \\ Kalimantan Barat \\ j.permata@stkippamanetalino.ac.id \\ ${ }^{2}$ Program Studi Pendidikan Matematika STKIP Pamane Talino, Jalan Afandi Rani, Ngabang, Landak, \\ Kalimantan Barat \\ yohanessandri183@gmail.com
}

First Received: 16-03-2020; Accepted: 28-04-2020

\begin{abstract}
Abstrak
Penelitian ini bertujuan untuk mendeskripsikan kemampuan siswa dalam memecahkan masalah menurut Polya. Jenis penelitian adalah kualitatif. Subjek dalam penelitian ini adalah 3 orang siswa yang mewakili tingkat kemampuan pemecahan masalah (Tinggi, Sedang, dan Rendah). Teknik pengumpulan data pada penelitian ini adalah tes dan wawancara. Teknik analisis data dalam penelitian ini meliputi reduksi data, penyajian data, menarik kesimpulan dan verifikasi. Hasil penelitian menunjukkan bahwa: (1) Siswa dengan kemampuan pemecahan masalah tingkat tinggi mampu melaksanakan tahap penyelesaian masalah Polya dengan baik dan benar. Siswa mampu menguasai 4 tahap pemecahan masalah Polya yakni pemahaman masalah, perencanaan, pelaksanaan rencana, dan pengecekan kembali. Subjek penelitian mampu memahami masalah dengan menuliskan apa yang diketahui dan ditanyakan serta mengucapkannya dengan menganalisis menggunakan kata-katanya sendiri, mampu menuliskan langkah pengerjaan secara lengkap (jawaban benar) dan mengecek kembali jawaban. (2) Siswa dengan kemampuan pemecahan masalah sedang mampu mengerjakan masalah yang diberikan hanya pada satu nomor soal, siswa memahami masalah dengan menuliskan yang diketahui dan ditanyakan, mampu menuliskan langkah penyelesaian masalah namun kurang lengkap, dan melaksanakan perencanaan dengan cukup baik karena dalam proses pengerjaan terdapat kekeliruan (jawaban salah) dan tidak melaksanakan pengecekan kembali karena belum mampu pada penyelesaian akhir soal. (3) Siswa dengan kemampuan pemecahan masalah rendah cenderung tidak memahami masalah, siswa tidak menuliskan apa yang diketahui dan ditanyakan, subjek penelitian dengan tingkat kemampuan pemecahan masalah rendah belum mampu memisalkan permasalahan sistem persamaan linear dua variabel dengan baik. Siswa belum mampu untuk melakukan langkah awal dengan memisalkan permasalahan nyata dalam soal.
\end{abstract}

Kata kunci: Kemampuan; Pemecahan masalah

\section{ANALYZE PROBLEM SOLVING ABILITY OF SMP MANIAMAS NGABANG STUDENTS}

\begin{abstract}
This study was designed to describe the ability of students to solve problems according to Polya. This type of research is qualitative descriptive. The subjects in this study were 3 students who represented problem-solving abilities (High, Medium and Low). Data collection techniques in this study were tests and interviews. Data analysis techniques in this study include data reduction, data
\end{abstract}


presentation and drawing conclusions and verification. The results of the study prove that: (1) Students with high-level problem solving skills can deal with problems with Polya properly and correctly. Students are able to master 4 problems solving Polya namely understanding the problem, planning, implementing the plan, and checking again. Research subjects are able to solve problems by expressing what is recognized and asked and refuted by using their own words, able to answer the steps of work correctly, and recheck answers. (2) Students who are able to solve existing problems Students who are able to overcome problems given only one problem, students who solve problems with the questions and questions asked, are able to solve incomplete problems, and manage planning well enough in the process of working. His working error (wrong answer), and do not check again because they are unable to solve the problem. (3) Students with low problemsolving ability Solve problems, Students do not understand what is meant and asked, research subjects with low problem-solving ability are able to assume the two-variable linear equation system well. Students have not been able to do the initial steps by thinking about real problems in the problem.

Keywords: Ability; Problem solving

\section{PENDAHULUAN}

Pembelajaran matematika merupakan satu diantara pembelajaran yang mempersiapkan SDM dalam bersaing di kemajuan dunia. Pemikiran dan penalaran yang dihasilkan dalam pembelajaran matematika memberikan dampak pada kesiapan siswa atau peserta didik dalam pemecahan masalah. Pembelajaran matematika merupakan suatu alat untuk mengembangkan cara berpikir, bersifat abstrak, penalarannya bersifat deduktif dan berkenaan dengan gagasan terstruktur yang hubungan-hubungannya diatur secara logis. Tujuan pendidikan menurut Sukardjo (2015:14) adalah memberikan penyadaran terhadap apa yang diketahuinya, kemudian pengetahuan tersebut harus direalisasikan sendiri dan selanjutnya mengadakan penelitian serta mengetahui hubungan kausal, yaitu alasan dan alur pikirannya. Matematika sebagai ratu ilmu merupakan ilmu dasar yang berkaitan dan menjadi pembangun dari ilmuilmu lain, baik aspek terapannya maupun aspek penalarannya mempunyai peranan penting dalam upaya penguasaan ilmu pengetahuan dan teknologi (Suherman dkk, 2003:25).

Peserta didik diharapkan mampu menggunakan matematika serta berpikir matematis dalam pemecahan masalah baik rutin maupun nonrutin. Hasil dari analisis data PISA 2013 dari Scherer \& Beckmann (2014) menyatakan bahwa kemampuan matematika dan kemampuan saintifik memberikan kontribusi yang signifikan dalam pemecahan masalah di seluruh negara. Salah satu kemampuan yang harus dimiliki siswa yang memberi dampak bagi kehidupan siswa baik di sekolah maupun saat siswa sudah lulus dari sekolah (Zevenbergen dkk, 2004:106). 
Tujuan dari pembelajaran matematika menurut Permendiknas No 22 Tahun 2006 agar peserta didik memiliki kemampuan: (1) memahami konsep matematika, menjelaskan katerkaitan antar konsep dan mengaplikasikan konsep atau algoritma, secara luwes, akurat, dan tepat, dalam problem solving, (2) menggunakan penalaran pada pola dan sifat, melakukan manipulasi matematika dalam membuat generalisasi, menyusun bukti, atau menjelaskan gagasan dan pertanyaan matematika, (3) memecahkan masalah yang meliputi kemampuan memahami masalah, merancang model matematika, menyelesaikan model dan menafsirkan solusi yang diperoleh, (4) mengkomunikasikan gagasan dengan simbol, tabel, diagram, atau media lain untuk memperjelas keadaan atau masalah, (5) memiliki sikap menghargai kegunaan matematika dalam kehidupan.

Pemecahan masalah merupakan bagian dari kurikulum matematika yang sangat penting karena dalam proses pembelajaran maupun penyelesaian, siswa dimungkinkan memperoleh pengalaman menggunakan pengetahuan serta keterampilan yang sudah dimiliki untuk diterapkan pada pemecahan masalah yang bersifat tidak rutin (Suherman, 2003:89). Kemampuan pemecahan masalah matematika dapat pula digunakan dalam pemecahan seharihari. Memecahkan masalah merupakan kemampuan dasar yang harus dimiliki oleh manusia, sama halnya dalam pemecahan masalah pembelajaran matematika. Marpaung (2007:2) menyatakan bahwa pembelajaran matematika sampai sekarang ini pada umumnya masih berlangsung didominasi oleh paradigma lama. Guru aktif mentransfer pengetahuan ke pikiran siswa (guru mengajari siswa). Sementara itu siswa menerima pengetahuan secara pasif (murid berusaha menghafal pengetahuan yang diterima). Hal inilah yang menyebabkan implementasi proses pemecahan masalah cenderung tidak berjalan dengan baik. Siswa belum terbiasa berpikir secara mandiri dalam penyelesaian masalah yang dihadapi.

Pemecahan masalah merupakan kemampuan yang sangat penting dalam pembelajaran matematika tetapi kemampuan pemecahan masalah di Indonesia masih sangat rendah. Hal ini terlihat pada rendahnya tingkat kemampuan pemecahan masalah ini dapat dilihat dari tes yang dilakukan oleh Trends in International Mathematics and Science Study (TIMSS) dan Program International Student Assesment (PISA). Laporan TIMSS pada tahun 2011 dalam Kemendikbud menunjukkan bahwa Indonesia berada pada urutan ke 38 dari 42 negara dengan rata-rata skor 386. Sedangkan pada laporan PISA tahun 2012 dalam OECD, rata-rata skor matematika yang dimiliki oleh Indonesia adalah 375 dan menempatkannya pada urutan ke 64 dari 65 negara yang mengikuti. Hal ini bukanlah termasuk prestasi yang membanggakan karena Indonesia menempati urutan lima terbawah pada TIMSS dan dua terbawah pada PISA. 
Pemecahan masalah dalam pembelajaran matematika adalah hal penting, hanya saja hal ini selalu menjadi kendala dan masalah dalam proses pemebelajaran. Siswa cenderung kesulitan dalam pemecahan masalah, hal ini sejalan dengan hasil penelitian yang dilakukan oleh Khasanah (2015) bahwa beberapa siswa masih mengalami kesulitan dalam memecahkan masalah dalam soal cerita.

Perlu adanya perhatian khusus dalam pembiasaan, peningkatan, dan analisis kemampuan pemecahan masalah. Penelitian ini menganalisis kemampuan pemecahan masalah siswa diharapkan dengan adanya hasil analisis ini dapat diketahui sejauh mana kemampuan pemecahan masalah dimiliki oleh siswa dalam penyelesaian masalah matematika yang dihadapi. Bahar dan Maker (2015) menyatakan bahwa konsep dari pemecahan masalah disebut oleh para ilmuwan sebagai proses berpikir tingkat tinggi yang terdiri dari kemampuan intelektual dan proses kognitif utama. Tahapan pemecahan yang akan dianalisis dalam penelitian adalah tahapan Polya: (1) memahami masalah, (2) membuat perencanaan, (3) melaksanakan perencanaan, (4) melakukan pengecekan kembali.

\section{METODE PENELITIAN}

Jenis penelitian yang digunakan dalam penelitian ini adalah jenis penelitian kualitatif deskriptif. Penelitian dilaksanakan di SMP Maniamas Ngabang kelas VII. Subjek penelitian adalah 3 (tiga) orang siswa dengan tingkat kemampuan pemecahan masalah tingkat tinggi, sedang, dan rendah. Teknik pengumpulan data pada penelitian ini adalah tes untuk menganalisis kemampuan pemecahan masalah dan wawancara untuk mendalami kemampuan pemecahan masalah siswa. Teknik analisis data dalam penelitian ini meliputi reduksi data, penyajian data, penarikan kesimpulan dan verifikasi.

\section{HASIL DAN PEMBAHASAN}

Pengambilan subjek penelitian diambil dengan menggunakan soal tes kemudian pelaksanaan wawancara secara individual dengan mempertimbangkan kemampuan subjek penelitian dalam memecahkan masalah soal sistem persamaan linier dua variabel. Berdasarkan metode pemecahan masalah Polya yang terdiri 4 (empat) tahap, yaitu pemahaman masalah, perencanaan, pelaksanaan rencana, dan pengecekan kembali. Kemampuan pemecahan masalah soal sistem persamaan linier dua variabel dengan langkah polya dengan tingkat kemampuan rendah, sedang, dan tinggi. 


\section{Kemampuan Pemecahan Masalah Tingkat Tinggi}

\section{a). Tahap pemahaman masalah}

1). Tes tertulis

Berikut merupakan jawaban pada tahap pemahaman masalah.

1. Diketatuhi $=$ buku $u$
misainga $=$ Pansil $y$
$84+6 y=19.900$
$64+5 y=11.200$
Ditanya: $56+8 y$

Gambar 1. Jawaban pada tahap pemahaman masalah

Berdasarkan hasil jawaban di atas terlihat bahwa subjek dapat memahami masalah. Hal ini dapat dilihat subjek dapat menulis semua informasi yang diketahui dengan lengkap buku $x$ dan pensil $y$. Selain itu subjek juga dapat menuliskan apa yang ditanya, yaitu $5 x+8 y$.

2). Analisis wawancara

Berikut merupakan hasil wawancara pada tahap memahami masalah.

$\mathrm{P} \quad$ : apakah kamu sudah mengerti tentang soal yang diberikan?

$\mathrm{S} \quad$ : mengerti pak

P : coba kamu sebutkan apa saja yang diketahui dan apa saja yang ditanya?

$\mathrm{S} \quad$ : buku tulis $x$ dan pensil $y$

Berdasarkan hasil wawancara di atas, terlihat bahwa subjek dapat menjelaskan pertanyaan yang diberikan dengan lancar yakni dengan mengetahui dari masalah buku $x$ dan pensil $y$. Subjek juga dapat menjelaskan apa yang ditanyakan pada soal tersebut.

\section{b). Tahap Perencanaan}

1). Tes tertulis

Berikut jawaban pada tahap membuat perencanaan.

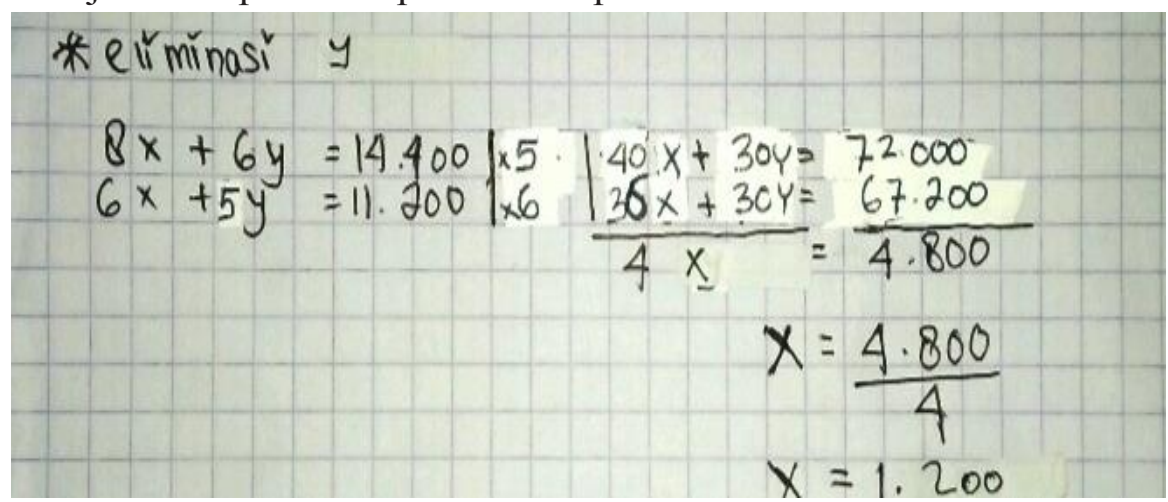

Gambar 2. Jawaban pada tahap membuat perencanaan 
Berdasarkan jawaban di atas, dapat dilihat siswa mampu membuat rencana penyelesaian dengan benar dan menggunakan metode elimasi untuk menentukan nilai $x$ sama dengan 1200 .

2). Analisis wawancara

Berikut hasil wawancara dengan subjek pada tahap membuat perencanaan.

$\mathrm{P} \quad$ : coba kamu sebutkan apa saja yang diketahui dan apa saja yang ditanya?

$\mathrm{S} \quad$ : diketahui sama dengan buku x misalnya pensil y. $8 x+6 y$ $=14.000$ dan $6 x+5 y=11.200$ diketahui $5 x+8 y$

$\mathrm{P} \quad$ : jelaskan langkah apa saja yang harus diselesaikan terlebih dahulu?

$\mathrm{S} \quad$ : eliminasi $x$

Berdasarkan wawancara di atas, subjek dapat membuat perencanaan penyelesaian dengan benar yakni dengan mengeliminasi salah satu variabel yang terdapat pada pertanyaan soal.

\section{c). Tahap Pelaksanaan rencana}

1). Tes tertulis

Berikut hasil jawaban subjek pada tahap pelaksanaan rencana.

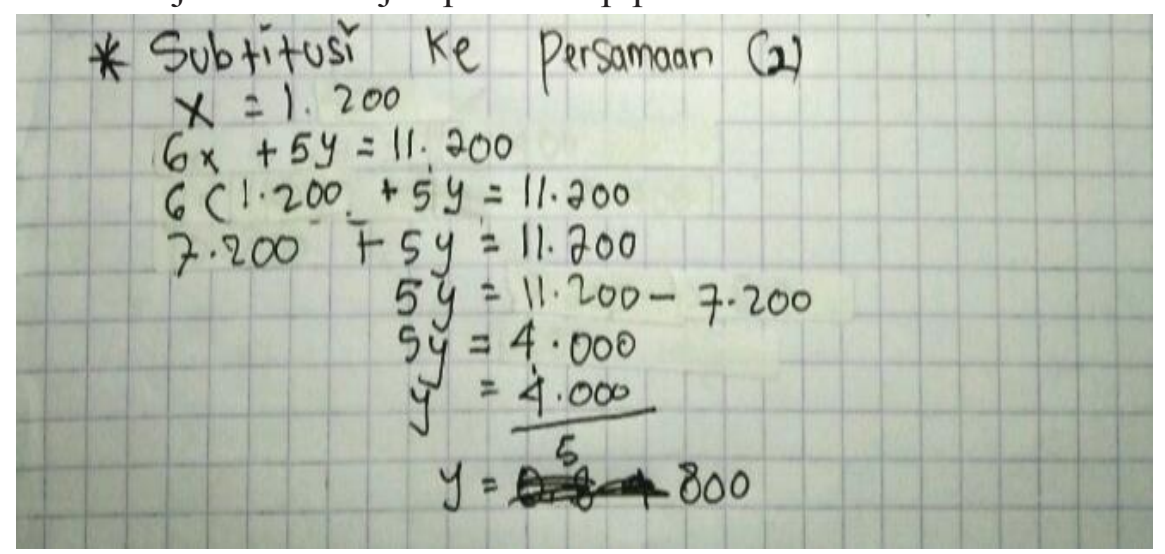

Gambar 3. Jawaban pada tahap pelaksanaan rencana

Berdasarkan jawaban di atas, Subjek dapat melaksanakan perencanaan penyelesaian dengan benar yakni menggunakan metode substitusi ke salah satu persamaan dengan $x$ sama dengan 1200 . Selanjutnya siswa juga dapat menentukan hasil nilai $y$ yaitu sama dengan 800 .

2). Analisis wawancara

Berdasarkan wawancara, subjek mampu melaksanakan perencanaan dengan baik dan secara berurutan yaitu dengan menggunakan metode substitusi ke persamaan satu guna untuk mencari nilai $x$. Berikut hasil wawancara tersebut.

$\mathrm{P} \quad$ : metode sistem persamaan apa yang digunakan dalam 
Mengerjakan soal tersebut?

S : substitusikan ke persamaan satu

$\mathrm{P} \quad$ : bagaimana cara terakhir dalam penyelesaian soal tersebut?

$\mathrm{S}: 5 x+8 y .4(3000)+4(51.000)+5(1000) .12 .000+$ $5.000=17.000$

\section{d). Tahap Pengecekan kembali}

1). Tes tertulis

Berikut hasil jawaban S1 pada tahap pengecekan kembali penyelesaian.

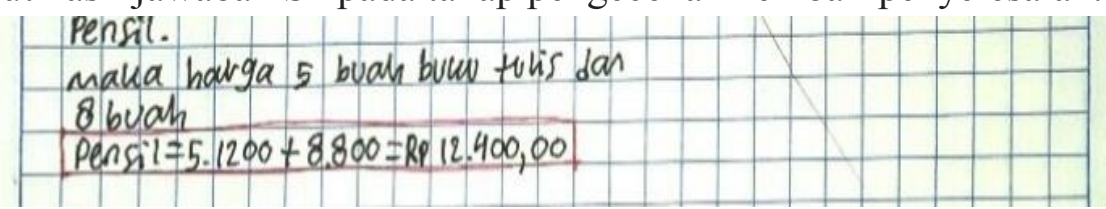

Gambar 4. Jawaban pada tahap pengecekan kembali

Berdasarkan hasil jawaban di atas, Subjek dapat menentukan kembali hasil akhir yang ditanyakan secara rinci setelah menentukan masing-masing nilai $x$ dan $y$, dengan benar. Selanjutnya subjek menentukan penyelesaian akhir yakni $5 x+8 y$ $=5(1.200)+8(8.800)=12.400$. Pada tahap akhir subjek mampu mengaitkan kembali pemisalan yang abstrak dengan permasalahan sesungguhnya di soal. Bisa dilihat pada kesimpulan terakhir subjek penelitian menunjukkan harga buku tulis dan harga pensil.

2). Analisis wawancara

Berikut hasil wawancara pada tahap pengecekan kembali penyelesaian.

$\mathrm{P}$ : bagaimana cara terakhir dalam penyelesaian soal tersebut?

$\mathrm{S}$ : pensil sama dengan 5.(1200) + 8.(800) $=12.400$

$\mathrm{P}$ : apakah kamu sudah yakin dengan cara penyelesaian terakhir yang telah dilakukan?

$\mathrm{S}$ : yakin

$\mathrm{S}$ : Bagaimana dengan tahap kesimpulan akhir yang kamu kaitkan kembali dengan buku dan pensil?

$\mathrm{S} \quad$ : saya mengingat bahwa soal membicarakan tentang buku dan pensil. Saya kembali mengingat pemisalan $x$ dan $y$.

Berdasarkan hasil wawancara di atas, Subjek mampu melaksanakan tahap pengecekan kembali pada penyelesaian terakhir yaitu mengecek soal yang ditanyakan.

Hasil analisis pemecahan masalah berdasarkan teori Polya di atas menunjukkan bahwa subjek dapat memahami masalah dengan baik. Dalam membuat rencana strategi pemecahan masalah subjek mampu melaksanakan rencana dengan baik dan rinci yakni dapat menggunakan metode penyelesaian sistem persamaan linier 
dua variabel. Subjek juga dapat menentukan pengecekan kembali terhadap soal yang ditanyakan dengan baik.

\section{Kemampuan Pemecahan Masalah Tingkat Sedang}

\section{a). Tahap pemahaman masalah}

1). Tes tertulis

Berikut hasil jawaban subjek pada tahap pemahaman masalah.

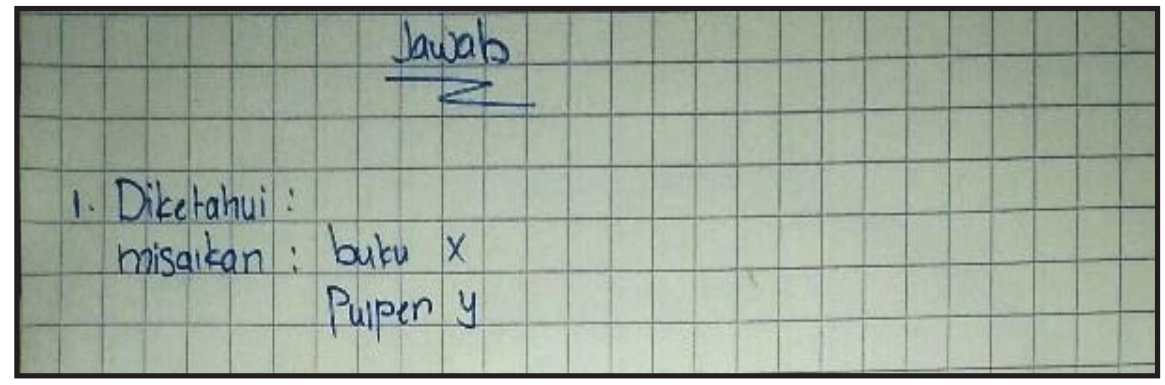

Gambar 5. Jawaban subjek pada tahap pemahaman masalah

Berikut hasil jawaban subjek di atas, subjek dapat memahami masalah yang terdapat pada soal dengan menulis apa yang diketahui yaitu misalkan buku $x$ dan pulpen $y$.

2). Analisis wawancara

Berikut hasil wawancara subjek pada pemahaman masalah

$\mathrm{P} \quad$ : apakah kamu mengerti tentang soal yang diberikan?

$\mathrm{S}$ : mengerti

$\mathrm{P} \quad$ : coba kamu sebutkan apa saja yang diketahui dan apa saja yang tanya?

$\mathrm{S}:$ diketahu misalkan buku $x$ dan pulpen $y 8 x+6 y=14.400$ dan $6 x+5 y=11.200$ ditanyakan $5 x+8 y$ ? eliminasi $x$ $8 x+=14.400$ dikali 5 dan $6 x+5 y=11.200$ dikali 6.5 dikali $8=40$ 5dikali $6=30$ hasilnya 72.000. 6 dikali 6 $=36.6$ dikali $5=30$ sama dengan 67.200.

$\mathrm{P}$ : jelaskan langkah apa saja yang harus diselesaikan terlebih dahulu?

$\mathrm{S} \quad$ : mengalikan $5 \times 8$

Berdasarkan hasil wawancara di atas, subjek dapat memahami masalah yang terdapat pada soal yang ditanyakan. Hal ini dapat dilihat dari cara subjek menjelaskan langkah penyelesaian dengan baik.

\section{b). Tahap perencanaan}

1). Tes tertulis

Berikut hasil jawaban subjek pada tahap perencanaan. 


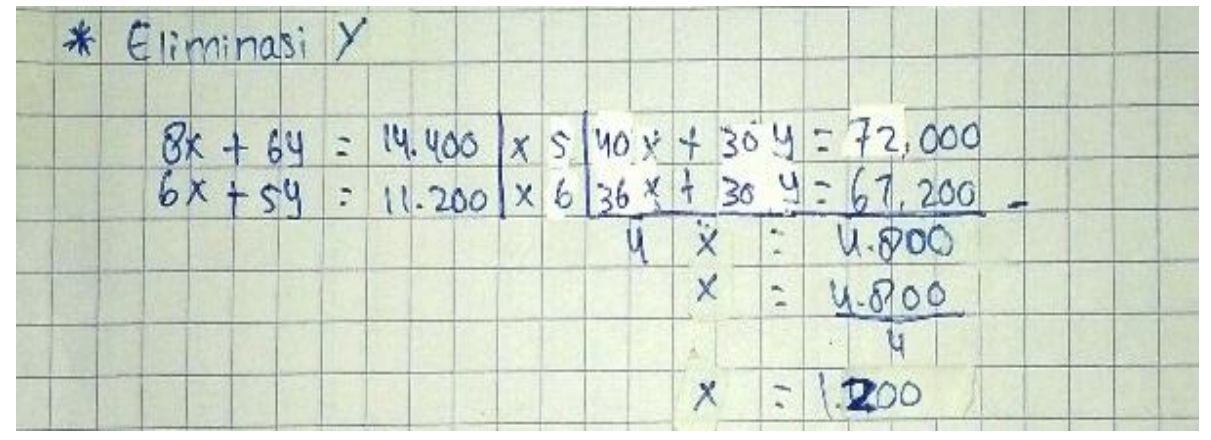

Gambar 6. Jawaban subjek pada tahap perencanaan

Berdasarkan jawaban subjek pada tahap perencanaan. Hal ini menunjukan bahwa subjek dapat menggunakan cara penyelesaian dengan metode eliminasi yakni untuk menentukan nilai dari $x$ serta menghilangkan variabel $y$ dengan benar.

2). Analisis wawancara

Berikut hasil wawancara subjek pada tahap perencanaan.

P : coba kamu sebutkan apa saja yang diketahui dan apa saja yang tanya?

$\mathrm{S} \quad$ : diketahu misalkan buku $x$ dan pulpen $y 8 x+6 y=14.400$ dan $6 x+5 y=11.200$ ditanyakan $5 x+8 y$ ? eliminasi $8 x$ $+=14.400$ dikali 5 dan $6 x+5 y=11.200$ dikali 6.5 dikali $8=40$ 5dikali $6=30$ hasilnya 72.000. 6 dikali $6=$ 36. 6 dikali $5=30$ sama dengan 67.200.

$\mathrm{P} \quad$ : jelaskan langkah apa saja yang harus diselesaikan terlebih dahulu?

$\mathrm{S} \quad$ : mengalikan $5 \times 8$

$\mathrm{P} \quad$ : metode sistem persamaan linier dua variabel apa yang kamu gunakan dalam menyelesaikan soal tersebut?

$\mathrm{S} \quad$ : kali dan bagi

Berdasarkan hasil wawancara di atas, subjek dapat menjelaskan langkahlangkah perencanaan pada penyelesaian yang dilakukan untuk penyelesaian soal hanya saja terdapat kesalahan pada metode penyelesaian sistem persamaan linier dua variabel yang digunakan dalam hal ini subjek menjawab dengan metode perkalian dan pembagian.

\section{c). Tahap pelaksanaan rencana}

1). Tes tertulis

Berikut hasil jawaban subjek pada tahap pelaksanan rencana. 


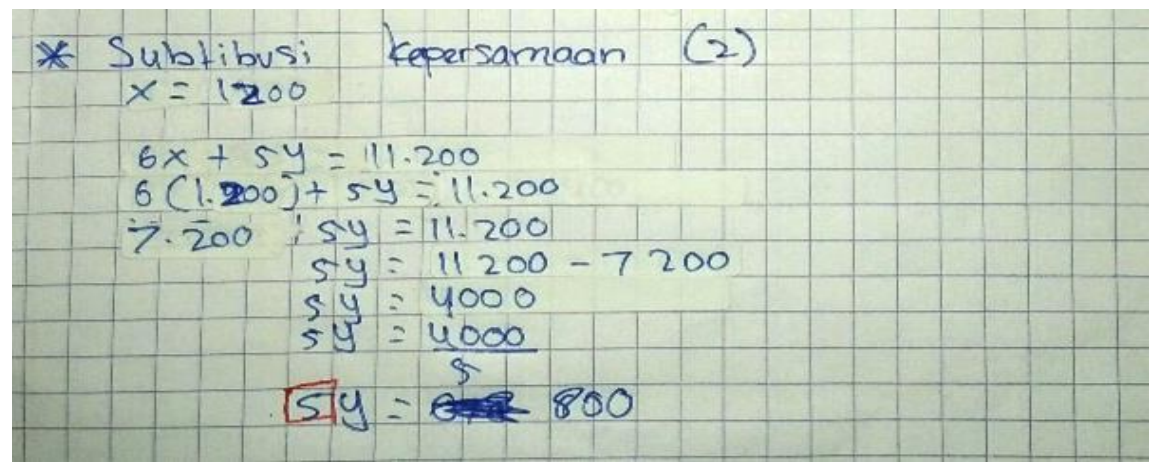

Gambar 7. Jawaban subjek pada tahap pelaksanaan rencana

Berdasarkan hasil jawaban subjek di atas, menunjukkan bahwa subjek mampu memahami masalah yang terdapat pada soal dengan melaksanakan rencana penyelesaian dengan baik, yakni subjek dapat menggunakan langkah subtitusi ke persamaan dua guna untuk menentukan nilai $y$ dengan benar. Hanya saja siswa belum mampu menyelesaikan soal dengan benar. Sehingga pada tahap akhir penyelesaian soal siswa belum mampu melaksanakan dengan benar.

2). Analisis wawancara

Berikut hasil wawancara subjek pada tahap pelaksanaan rencana.

$\mathrm{P} \quad$ : apakah kamu mengerti tentang soal yang diberikan?

$\mathrm{S} \quad$ : mengerti

P : coba kamu sebutkan apa saja yang diketahui dan apa saja yang tanya?

$\mathrm{S} \quad$ : diketahu misalkan buku $x$ dan pulpen $y 8 x+6 y=14.400$ dan $6 x+5 y=11.200$ ditanyakan $5 x+8 y$ ? eliminasi $x$ $8 x+=14.400$ dikali 5 dan $6 x+5 y=11.200$ dikali 6.5 dikali $8=405$ dikali $6=30$ hasilnya 72.000. 6 dikali $6=$ 36. 6 dikali $5=30$ sama dengan 67.200.

$\mathrm{P} \quad$ : jelaskan langkah apa saja yang harus diselesaikan terlebih dahulu?

$\mathrm{S} \quad$ : mengalikan $5 \times 8$

$\mathrm{P} \quad$ : metode sistem persamaan linier dua variabel apa yang kamu gunakan dalam menyelesaikan soal tersebut?

$\mathrm{S} \quad$ : kali dan bagi

Berdasarkan hasil wawancara di atas, subjek dapat menjelaskan tahap pelaksanaan rencana penyelesaian soal dengan baik.

\section{d). Tahap pengecekan kembali}

1). Tes tertulis

Subjek tidak melakukan tahap pengecekan kembali pada penyelesaian akhir yang ditanyakan. Hal ini dikarenakansubjek belum mampu menyelesaikan soal yang diberikan dengan baik pada penyelesaian akhir. 
2). Analisis wawancara

Berikut hasil wawancara subjek pada tahap pengecekan kembali.

$\mathrm{P} \quad$ : metode sistem persamaan linier dua variabel apa yang kamu gunakan dalam menyelesaikan soal tersebut?

$\mathrm{S} \quad$ : kali dan bagi

$\mathrm{P} \quad$ : bagaimana cara terakhir dalam menyelesaikan soal tersebut?

S : haslinya dibagi

$\mathrm{P} \quad$ : apakah kamu sudah yakin dengan cara penyelesaian yang telah kamu lakukan?

$\mathrm{S} \quad$ : yakin

Berdasarkan penjelasan subjek di atas, subjek dapat melakukan pengecekan kembali pada penyelesaian soal. Meskipun pada tes tertulis subjek tidak dapat melaksanakan penyelesaian akhir.

Berdasarkan hasil analisis di atas dapat disimpulkan subjek auditorial dapat memecahkan masalah yang terdapat pada soal sistem persamaan linier dua variabel dengan melaksanakan langkah-langkah pemecahan masalah menurut Polya yaitu, memahami masalah, perencanaan pemecahan masalah, pelaksanaan rencana, dan pegecekan kembali.

\section{Kemampuan Pemecahan Masalah Tingkat Rendah}

a. Tes Tertulis

Subjek penelitian dengan kemampuan pemecahan masalah tingkat rendah memiliki kendala pada tahap awal penyelesaian masalah yakni siswa belum mampu memahami masalah pada soal Persamaan Linear Dua Variabel dengan baik. Sehingga pada tahap selanjutnya yakni perencanaan, pelaksanaan rencana, dan pengecekan kembali siswa tidak mampu melaksanakannya dengan baik. Hal ini menjadi fokus bagaimana pembiasaan kepada siswa dalam tahap pertama memahami permasalahan yang harus dilakukan dalam penyelesaian masalah.

\section{b. Analisis Wawancara}

$\mathrm{P} \quad$ : Mengapa lembar jawaban tidak kamu isi?

$\mathrm{S}$ : Saya tidak mengerti apa yang harus saya lakukan.

$\mathrm{P} \quad$ : apakah kamu tidak memahami masalah yang diberikan soal dalam menentukan harga buku dan pensil.

$\mathrm{S}$ : saya tidak paham.

\section{SIMPULAN}

Berdasarkan analisis data di atas, dalam pemecahan masalah menurut Polya pada materi sistem persamaan linier dua variabel dapat disimpulkan sebagai berikut. (1) subjek dengan kemampuan pemecahan masalah tingkat tinggi pada tahap memahami masalah subjek mampu 
mengetahui masalah yang terdapat pada soal. Dalam hal ini subjek dapat menulis apa yang diketahui dan ditanya. Pada tahap perencanaan subjek dapat membuat rencana pemecahan soal dengan cara mengeliminasi salah satu variabel dengan cara sendiri. Pada tahap pelaksanaan rencana subjek dapat melanjutkan suatu rencana yang telah dilakukan sebelumnya guna untuk mengetahui kedua nilai variabel $x$ dan $y$ yakni dengan metode subtitusi ke salah satu persamaan sistem persamaan linier dua variabel. Sehingga subjek dengan pemecahan masalah tingkat tinggi dapat melaksanakan pengecekan kembali pada topik pertanyaan soal dengan langkah penyelesaian yang benar dan rinci. (2) subjek dengan kemampuan pemecahan masalah tingkat sedang pada tahap memahami masalah subjek dapat mengetahui masalah dengan baik yaitu dengan menulis diketahui dan ditanya. Pada tahap membuat rencana pemecahan masalah subjek sudah melakukan langkah peyelesaian awal dengan baik yakni dapat menggunakan metode eliminasi. Tahap pelaksanaan rencana subjek juga tidak dilakukan dengan benar sehingga pada tahap akhir penyelesaian soal, subjek penelitian belum mampu melaksanakan perencanaan soal dengan benar. Pada tahap pengecekkan kembali subjek mengalami masalah pada penyelesaian akhir yang ditanyakan pada soal sehingga dalam hal ini subjek tidak dapat memenuhi prosedur pemecahan masalah dengan secara rinci pada pelaksanaan rencana penyelesaian masalah dan tahap pengecekkan kembali. Kenyataan di lapangan menunjukkan bahwa kegiatan pemecahan masalah matematika belum dijadikan sebagai kegiatan utama.

\section{DAFTAR PUSTAKA}

Bahar and Maker (2015). Cognitive Backgrounds of Problem Solving: A Comparison of Open-ended vs. Closed Mathematics Problems. Eurasia Journal of Mathematics, Science \& Technology Education,2015, 11(6), 1531-1546

Khasanah, U. (2015). Kesulitan Menyelesaikan Soal Cerita Matematika Pada Siswa SMP. Artikel Pendidikan Matematika Fakultas Keguruan Dan Ilmu Pendidikan Universitas Muhammadiyah Surakarta.

Marpaung, Y. (2007). Karakteristik PMRI (Pendidikan matematika realistik indonesia). Disajikan pada Penataran dan Lokakarya Widyaiswara Matematika LPMP Angkatan I dan II, di PPPG Matematika Yogyakarta.

Polya, G. (1973). How to Solve it: A new Aspect of Mathematical Method (2nd ed). New Jersey: Princenton University Press.

Program International Student Assesment (PISA) pada tahun 2012. 
Scherer \& Beckmann. (2014), The acquisition of problem solving competence : evidence from 41 countries that math and science education matters.large-scale Assesment in Education.

Suherman, (2003). Strategi Pembelajaran Matematika Kontemporer.Jurusa Pendidikan Matematika. Universitas Pendidikan Indonesia.

Sukardjo \& Ukim K. (2015). Landasan Pendidikan Konsep dan Aplikasinya. Jakarta: Rajawali Pres.

Trends in International Mathematics and Science Study (TIMSS) pada tahun 2011.

Zevenbergen, Shelley Dole, and Robert J. Wrigh. (2004). Teaching Mathematics in Primary School. Allen \& Unwin:Australia. 